\title{
Idea miast partnerskich wobec wybranych uchwał samorządowych w Polsce w latach 2019-2020
}

Abstrakt: Celem niniejszego artykułu jest przybliżenie problematyki związanej z zawieszaniem przez niektóre miasta europejskie współpracy partnerskiej z miastami polskimi, w których przyjęte zostały uchwały lub deklaracje „anty-LGBT”. Tłem opracowania jest historia zawiązywania się wzajemnej współpracy pomiędzy miastami i regionami w Europie. Pokazano także aktualny stan partnerstwa pomiędzy lokalnymi ośrodkami w Polsce, które podpisały umowy o wielostronnej współpracy z wybranymi miastami za granicą. Dokonano analizy wybranych przekazów medialnych, które na przełomie 2019 i 2020 roku dotyczyły omawianej problematyki. W efekcie podjęto próbę scharakteryzowania problemu, określenia jego potencjału i ewentualnych dalszych skutków dla idei miast partnerskich oraz przeanalizowano możliwe skutki społeczne, prawne i kulturowe na przykładzie zerwania partnerstwa przez francuskie miasto Saint-Jean-de-Braye z polskim Tuchowem metodą case study oraz metodą analizy zawartości ${ }^{1}$.

Słowa kluczowe: miasta partnerskie, współpraca, regiony, samorząd, LGBT

\section{The idea of partner cities toward selected local government resolutions} in Poland in the years 2019-2020

Abstract: The aim of this article is to present the issues related to the suspension by some European cities of cooperation with Polish cities where "anti-LGBT" resolutions or declarations have

${ }^{1}$ M. Lisowska-Magdziarz, Analiza zawartości mediów. Przewodnik dla studentów. Wersja 1.1, Kraków 2004; T. Gackowski, K. Brylska, M. Patera, Korzystanie z mediów społecznościowych jako praktyka społeczna różnych pokoleń medialnych, Warszawa 2018; T. Gackowski, Metodologie badań medioznawczych, Warszawa 2014; A. Szymańska, M. Lisowska-Magdziarz, A. Hess, Metody badań medioznawczych i ich zastosowanie, Kraków 2018; T. Pawłuszko, Wstęp do metodologii badań politologicznych, Częstochowa 2013. 
been adopted. The background of the study is the history of establishing mutual cooperation between cities and regions in Europe. The current state of partnership between local centers in Poland, which signed multilateral cooperation agreements with selected cities abroad, was also shown. An analysis of selected media messages was made which concerned the discussed issues at the turn of 2019 and 2020.

As a result, an attempt was made to characterize the problem, determine its potential and possible further effects on the idea of partner towns, and analyze the possible social, legal, and cultural effects by the example of breaking the partnership by the French city of Saint-Jean-de-Braye with the Polish town of Tuchów, using the case-study method and the method of contents' analysis.

Keywords: Partner cities, cooperation, regions, local government, LGBT

\section{Wstęp}

Próbując znaleźć odpowiedź na pytanie „czym jest partnerstwo?”, bez podziału na podmioty, struktury, rodzaje, sposoby realizacji zadań, geografię czy kompetencje, najczęściej spotykamy się z określeniami oznaczającymi współpracę, zaufanie, pomoc i wzajemność.

Profesor Jerzy Marchwiński ${ }^{2}$ w tekście wygłoszonym podczas Konferencji Naukowo-Artystycznej na Uniwersytecie Muzycznym Fryderyka Chopina w Warszawie w dniu 6 kwietnia 2014 roku $^{3}$, podejmując próbę opisu pojęcia partnerstwo, posłużył się definicją z The Encyclopedia Britannica, która (w tłumaczeniu) brzmi następująco: „Partnerstwo, dobrowolny związek dwu lub więcej osób, którego celem jest prowadzenie przedsięwzięcia oraz dzielenie jego zysków lub strat". W dalszej części wystąpienia profesor Marchwiński, odnosząc się co prawda do świata sztuki (muzyki, kompozycji, wykonań itp.), przedstawia refleksję, że „podobnie jak kultura i wszelkie kreatywne relacje pomiędzy ludźmi, nic nie dzieje się samo. Wszystko wymaga wysiłku, zaangażowania, mądrości, wytrwałości, może też w pewnym sen-

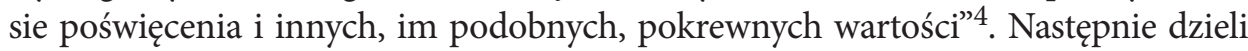
się wybranymi przez siebie wartościami, które, choć przypisane do świata muzyki, w opinii autora niniejszego artykułu okazują się uniwersalnymi wskazaniami, które oddają istotę partnerstwa ogólnie. Są to: odpowiedzialność, wzajemność, rozumienie partnera, otwarcie na dialog, gotowość rozumienia odmienności partnera, wewnętrzna przestrzeń, zdolność równoczesnego słyszenia siebie i partnera, kultura bycia $\mathrm{z}$ drugim człowiekiem, takt $\mathrm{w}$ rozwiązywaniu napięć, zdolność akceptowania kompromisu, zaufanie i szacunek do partnera, rozumienie niedoskonałości partnera i swoich własnych ${ }^{5}$. W dalszej części niniejszego opracowania, choć profesor Marchwiński zastrzega, że wskazania te traktuje jako osobiste odniesienia do definicji

${ }^{2}$ Pianista-kameralista i pedagog (urodzony w 1935 roku), https://culture.pl/pl/tworca/jerzy-marchwinski (dostęp: 21.02.2020).

3 J. Marchwiński, Definicja partnerstwa. Próba wyjaśnienia pojęcia, http://jerzy-marchwinski. blogspot.com/2014/04/definicja-partnerstwa.html (dostęp: 21.02.2020).

4 Ibidem.

${ }^{5}$ Ibidem. 
partnerstwa, postarano się wykazać, że są one uniwersalne również w przypadku partnerstwa miast i regionów. Stanowią także swoiste odniesienie do zagadnień dotyczących związków partnerskich (rozumianych inaczej niż małżeństwo, czyli związek kobiety i mężczyzny, zgodnie $\mathrm{z}$ art. 18 Konstytucji $\mathrm{RP}^{6}$ ), które były istotnym elementem tak zwanych uchwał anty-LGBT ${ }^{7}$.

\section{Geneza, rozwój i uwarunkowania prawne ruchu miast partnerskich w Europie}

Współpraca miast partnerskich ${ }^{8}$, której celem są przedsięwzięcia na płaszczyznach gospodarczych, kulturalnych i promocyjnych, narodziła się wkrótce po zakończeniu drugiej wojny światowej. Choć za pierwowzór takich działań uznaje się kontakty niektórych gmin Francji i Wielkiej Brytanii po pierwszej wojnie światowej, a czasami nawet związki miast w Europie Północno-Zachodniej w okresie od XII do XVII wieku (Hanza, Związek Hanzeatycki, Liga Hanzeatycka ${ }^{9}$ ), to jednak początek porozumień pomiędzy miastami, w kształcie podobnym do tego, który znamy dziś, datuje się na 1947 rok. W tym roku przedstawiciele francuskiego miasta Montbéliard i niemieckiego Ludwisburg podpisali umowę o wzajemnej współpracy ${ }^{10}$. Działania te uznawane są dziś za impuls do podobnych przedsięwzięć wśród miast i regionów, których państwa jeszcze niedawno prowadziły wobec siebie wrogie działania wojenne.

Wydarzenie to zapoczątkowało proces utworzenia Rady Gmin Europejskich w 1951 roku przez pięćdziesiąt europejskich gmin. Instytucja ta, po rozszerzeniu zakresu swoich działań również o całe regiony, przyjęła nazwę Rady Gmin i Regionów Europy ${ }^{11}\left(\mathrm{CEMR}^{12}\right)$. CEMR, zrzeszająca obecnie około stu tysięcy przed-

${ }^{6}$ Konstytucja Rzeczypospolitej Polskiej, art. 18.: „Małżeństwo jako związek kobiety i mężczyzny, rodzina, macierzyństwo i rodzicielstwo znajdują się pod ochroną i opieką Rzeczypospolitej Polskiej" (dostęp: 21.02.2020).

7 Skrót LGBT (ang. Lesbian, Gay, Bisexual, Transgender) odnoszący się do ruchu lesbijek, gejów, osób biseksualnych i transseksualnych; spotkać można również skrót LGBTQ, gdzie litera Q oznacza queer (osoby nieheteroseksualne) lub questioning (osoby niepewne swojej orientacji seksualnej). W przypadku skrótu LGBTI litera I odnosi się do słowa „interseksualizm”. Skrót LGBT+ pojawił się jako próba nazewniczego scalenia środowiska, a także jako określenie osób należących do tego ruchu oraz wspierających.

${ }^{8}$ Również: miasta siostrzane (ang. sister cities), miasta bliźniacze (ang. twinned towns) lub miasta braterskie (w krajach dawnego obozu socjalistycznego).

9 „Hanza była związkiem kupców, którzy prowadzili handel z dalekimi krajami. Związek powstał w połowie XII wieku i przez prawie 400 lat był w Europie liczącym się graczem. Centralny obszar handlowy kupców Hanzy rozpościerał się aż po Brugię i Londyn na zachodzie, po Nowogród daleko na wschodzie, a na północy aż po norweskie Bergen" - A. Bär, Sieć zaufania, https://www. goethe.de/ins/pl/pl/kul/mag/21444138.html (dostęp: 21.02.2020).

${ }^{10}$ M. Misztal, Rola samorządów lokalnych $w$ kształtowaniu tolerancji i integracji międzynarodowej, „Ekonomiczne Problemy Usług” 61, 2010, nr 620, s. 252.

11 Od 1984 roku.

12 The Council of European Municipalities and Regions. 
stawicieli lokalnych władz spośród trzydziestu dziewięciu krajów, jest jedną z największych tego typu organizacji w Europie ${ }^{13}$.

Swoje cele, skupione wokół działań na rzecz lokalnych i regionalnych samorządów, realizuje poprzez pomoc lokalnym strukturom samorządowym, aby miały one wymierny wpływ na europejskie prawo i politykę. Równie ważnym zadaniem jest stwarzanie pola do wymiany doświadczeń na poziomie lokalnym i regionalnym ${ }^{14}$.

Kolejne lata po powstaniu Rady Gmin Europejskich przyniosły dalszy, dynamiczny rozwój idei, która zyskała miano ruchu miast bliźniaczych, obejmując swym zasięgiem całą Europę Zachodnią. Zauważmy, że proces odbywał się ledwie dziesięć lat po zakończeniu drugiej wojny światowej, społeczność międzynarodowa stanęła zaś u progu kolejnego konfliktu, który, choć nie przybrał charakteru otwartych działań wojennych, to na długie lata określony został mianem „zimnej wojny”. Joanna Szewczyk w opracowaniu Zagraniczne związki partnerskie polskich samorządów, miast i województw zauważa, że: „społeczeństwa państw, które były uczestnikami II wojny światowej, zdały sobie sprawę z tego, że jedynie wzajemna współpraca, oparta na przyjaźni zwykłych mieszkańców, może zapobiec kolejnej wojnie"15.

Za realny przełom $\mathrm{w}$ relacjach miast partnerskich, który okazał się prawdziwie nowym otwarciem w budowie integracji europejskiej, uznaje się dziś niemiecko-francuski układ o przyjaźni z 1963 roku $^{16}$. Lata siedemdziesiąte i osiemdziesiąte XX wieku przyniosły dalszy rozwój życia społeczno-gospodarczego w obszarach transgranicznych, co zaowocowało rozkwitem stosunków międzynarodowych pomiędzy jednostkami samorządowymi. Wspomniany rozwój przyniósł formalizację zawieranej współpracy. Spośród powstałych uregulowań prawnych pierwszym, scalającym dotychczasowe doświadczenia, ale również wyznaczającym nowe kierunki działań była Europejska konwencja ramowa o współpracy transgranicznej między wspólnotami i władzami terytorialnymi ${ }^{17}$, podpisana w Madrycie 21 maja $1980 \mathrm{roku}^{18}$. W następnych latach podpisywano kolejne międzynarodowe akty normatywne definiujące prawa i obowiązki wynikające ze współpracy transgranicznej. Spośród nich do najbardziej istotnych należą:

— Europejska karta regionów granicznych i transgranicznych (do 1995 roku istniejąca jako Europejska karta regionów przygranicznych), uchwalona przez Radę Europy w dniu 19 listopada 1981 roku; przyjęta przez Polskę w 1995 roku ${ }^{19}$;

13 Rada Gmin i Regionów Europy (CEMR), https://www.zpp.pl/artykul/62-rada-gmin-i-regionow-europy-cemr (dostęp: 11.02.2020).

14 Ibidem.

15 J. Szewczyk, Zagraniczne związki partnerskie polskich samorząów, miast i województw, „Prace Geograficzne" 2007, z. 117, s. 259.

16 Ibidem.

17 H. Izdebski, Samorząd terytorialny. Podstawy ustroju i działalności, Warszawa 2011, s. 443.

18 Ratyfikowana przez Polskę dnia 10 marca 1993 roku.

19 I. Wieczorek, A. Głąb, Zadania administracji samorządowej w zakresie wspótpracy transgranicznej, [w:] Wybrane aspekty wspótpracy transgranicznej polskich samorząów w kontekście przemian prawa Unii Europejskiej, red. I.M. Wieczorek, M. Ganczar, Łódź 2016, s. 10. 
- Europejska karta samorządu lokalnego, uchwalona dnia 15 października 1985 roku w Strasburgu; ratyfikowana przez Polskę w 1993 roku$^{20}$;

- Europejska karta samorządu regionalnego, przyjęta w 1997 roku przez Kongres Władz Lokalnych i Regionalnych ${ }^{21}$.

Wymienione akty prawne definiują pojęcia współpracy transgranicznej oraz jej kompetencje, a także określają wzorce współpracy pomiędzy stronami w wymiarze zarówno prawnym, jak i administracyjno-technicznym. Kładą również nacisk na współpracę transgraniczną o charakterze oddolnym i apelują o podejmowanie działań ukierunkowanych na osiąganie wspólnych celów poprzez organizacje, przedsiębiorstwa oraz mieszkańców poszczególnych regionów ${ }^{22}$.

\section{Współpraca międzynarodowa polskich miast, gmin i regionów}

Początki współpracy lokalnych społeczności z ośrodków polskich i zagranicznych sięgają czasów PRL. Okres ten można podzielić na „współpracę państw obozu socjalistycznego", która jednak narzucona została odgórnymi wytycznymi ze strony aparatu władzy, oraz na nieliczne kontakty z miastami państw Europy Zachodniej, na przykład Francji, Belgii czy Republiki Federalnej Niemiec. Do drugiej grupy zaliczyć można przykłady Kalisza i francuskiego Hautmont, które w 1958 roku podpisały Kartę przyjaźni ${ }^{23}$, Rybnika, który w 1961 roku podpisał umowę o współpracy z kolejnym miastem „zza żelaznej kurtyny”, francuskim Saint Vallier ${ }^{24}$, czy trwającą od 1987 roku partnerską współpracę Wrocławia z niemieckim Wiesbaden ${ }^{25}$.

Właściwa współpraca partnerska pomiędzy miastami, gminami czy regionami rozwinęła się na początku lat dziewięćdziesiątych XX wieku w okresie transformacji ustrojowej państw Europy Środkowej i Wschodniej. Od tego okresu datuje się wzmożoną aktywność społeczności lokalnych, do której przyczyniły się zmiany w relacjach z innymi państwami po 1989 roku. Niebagatelną rolę w możliwości podejmowania ponadgranicznego współdziałania odegrała też w Polsce reforma administracyjna z 1999 roku, określająca na nowo zasady funkcjonowania jedno-

${ }^{20}$ Ibidem.

21 Ibidem.

22 Ibidem.

${ }^{23}$ Miasta partnerskie - dlaczego warto współpracować, https://samorzad.infor.pl/sektor/rozwoj_i_promocja/wspolpraca/2960129,Miasta-partnerskie-dlaczego-warto-wspolpracowac.html. amp (dostęp: 12.03.2020).

24 B. Kubica, Jak górnicy z Rybnika swoja przyjaźń z miastem zza „żelaznej kurtyny” zaczynali, https://plus.dziennikzachodni.pl/jak-gornicy-z-rybnika-swoja-przyjazn-z-miastem-zza-zelaznej-kurtyny-zaczynali/ar/4995386 (dostęp: 11.03.2020).

${ }^{25}$ M. Wieliczko, Od Gauadalajary do Ramat Gan - umowy partnerskie Wrocławia, https:// www.wroclaw.pl/portal/miasta-partnerskie-wroclawia (dostęp: 11.03.2020). 
stek samorządu terytorialnego. Współpraca międzynarodowa przyczyniała się do wymiany doświadczeń oraz umacniała świadomość obywatelską, a także promowała lokalną demokrację ${ }^{26}$. Była też ważnym elementem przygotowań do członkostwa Polski w strukturach Unii Europejskiej, a w późniejszej fazie — sposobach pozyskiwania i wykorzystywania funduszy europejskich.

Jeżeli chodzi o zakres prawny podstaw nawiązywania współpracy międzynarodowej przez jednostki samorządu terytorialnego w Polsce, to badacze problemu są zgodni, że źródeł polskich przepisów regulujących międzynarodową współpracę samorządów należy szukać w ratyfikacji Europejskiej karty samorządu lokalnego oraz w art. 172 Konstytucji RP z kwietnia $1997 \mathrm{roku}^{27}$. Do innych istotnych aktów prawnych dotyczących zasad współpracy międzynarodowej na poziomie regionalnym należą:

- ustawa z dnia 8 marca 1990 roku o samorządzie gminnym,

- ustawa o samorządzie powiatowym z dnia 5 czerwca 1998 roku,

- ustawa o samorządzie województwa z dnia 5 czerwca 1998 roku,

- ustawa o zasadach przystępowania jednostek samorządu terytorialnego do międzynarodowych zrzeszeń społeczności lokalnych i regionalnych z dnia 15 września $2000 \mathrm{roku}^{28}$.

W ostatnim z wymienionych aktów prawnych zawarte zostały szczegółowe przepisy regulujące zasady przystępowania jednostek samorządu terytorialnego do międzynarodowych zrzeszeń społeczności lokalnych i regionalnych. Ustawa określa kwestie dotyczące przynależności i uczestnictwa oraz granice zadań i kompetencji. Jednocześnie podporządkowuje te działania polskiemu prawu wewnętrznemu, polityce zagranicznej państwa i jego zobowiązaniom międzynarodowym. Należy też nadmienić, że zgodę na przystąpienie jednostki samorządu terytorialnego do stowarzyszenia o charakterze międzynarodowym musi wyrazić minister spraw zagranicznych.

Polskie miasta, gminy, powiaty i regiony nawiązały blisko cztery tysiące partnerstw z różnymi jednostkami samorządu terytorialnego ${ }^{29}$. Rekordzistami wśród miast, biorąc pod uwagę liczbę podpisanych umów, są Kraków (22), Łódź i Gdańsk (po 20), a wśród regionów - województwo kujawsko-pomorskie $(16)^{30}$. Na stronie twinning.org, administrowanej przez CEMR, znajduje się „10 kroków do sukcesu [w realizacji partnerstwa - T.K.]” . W większości przypadków partnerstwo miast czy regionów zaczyna się od szukania się na zasadzie podobieństw, na przykład liczby mieszkańców, położenia, gospodarki, historii, sprawy społecznych itp. Warto wymienić też inne ważne cele, między innymi zaangażowanie mieszkańców,

26 J. Szewczyk, op. cit., s. 261; M. Szewczak, I. Wieczorek, Wspótpraca międzynarodowa miast polskich. Doświadczenia JST, Łódź 2018, s. 22.

27 M. Misztal, op. cit., s. 253.

28 B. Nitschke-Szram, Międzynarodowa współpraca samorząów, „Opinie i Ekspertyzy” 2017, nr 261, s. 8.

29 Wspótpraca miast partnerskich, http://www.miasta.pl/strony/wspolpraca-miast-partnerskich (dostęp: 12.03.2020).

${ }^{30}$ Miasta partnerskie... 
współpracę ze szkołami i młodzieżą. Z punktu widzenia niniejszego opracowania niesłychanie istotne wydają się zapisy kroku ósmego: „Pamiętaj o zrównoważonych relacjach. Dobre partnerstwo musi przetrwać próbę czasu. Prawdziwe przyjaźnie, zaufanie i relacje między ludźmi rodzą się z czasem"31.

\section{Samorządowe uchwały „anty-LGBT” w Polsce w latach 2019-2020. Reakcja miast partnerskich z Europy Zachodniej}

Rafał Trzaskowski, prezydent miasta stołecznego Warszawy, 18 lutego 2019 roku podpisał deklarację LGBT+ ${ }^{32}$. Dokument powstał jako odpowiedź na inicjatywy programu samorządowego Stowarzyszenia „Miłość Nie Wyklucza” we współpracy z czterema innymi warszawskimi organizacjami LGBT ${ }^{33}$. Była to także realizacja jednego z postulatów Rafała Trzaskowskiego, które przedstawił w czasie kampanii przed wyborami samorządowymi w 2018 roku. Podpisanie deklaracji oznaczało realizację postulatów środowiska LGBT+, a w efekcie wdrażanie wypracowanych rozwiązań:

- w obszarze bezpieczeństwa: reaktywacja hostelu interwencyjnego dla osób LGBT+ będących w trudnej sytuacji życiowej, zmuszonych do opuszczenia domu; stworzenie miejskiego mechanizmu zgłaszania, monitorowania przestępstw wynikających z homofobii i transfobii; wzmocnienie działań antyprzemocowych w szkole;

- w dziedzinie edukacji: edukacja antydyskryminacyjna i seksualna zgodna ze standardami WHO, aktywne wspieranie nauczycieli, otwartość na inicjatywy trzeciego sektora dotyczące spraw społeczności;

- w obszarze kultury i sportu: patronat prezydenta miasta nad Paradą Równości, stworzenie centrum kulturowo-społecznościowego dla osób LGBT+, wsparcie klubów sportowych skupiających osoby LGBT+;

- w obszarze pracy: podpisanie Karty Różnorodności i współpracy z pracodawcami przyjaznymi osobom LGBT+;

- w obszarze administracji: rozszerzenie stosowania klauzul antydyskryminacyjnych w umowach $\mathrm{z}$ kontrahentami miasta ${ }^{34}$.

W podpisanym dokumencie zadeklarowano również powołanie w strukturach urzędu pełnomocnika prezydenta miasta stołecznego Warszawy do spraw społeczności LGBT $+{ }^{35}$.

${ }^{31}$ Dziesięć kroków do sukcesu, http://www.twinning.org/pl/page/dziesi\%C4\%99\%C4\%87-krok \%C3\%B3w-do-sukcesu\#.XpT5D2DgrIU (dostęp: 16.03.2020).

32 J. Michalak, Prezydent stolicy podpisał Deklarację LGBT+, https://www.um.warszawa.pl/aktualnosci/prezydent-stolicy-podpisa-deklaracj-lgbt (dostęp: 18.03.2020).

33 Ibidem.

${ }^{34}$ Ibidem.

35 Ibidem. 
Deklaracja, a w szczególności zapowiedź wprowadzenia w warszawskich szkołach edukacji antydyskryminacyjnej i seksualnej według wytycznych Światowej Organizacji Zdrowia, wzbudziła również wiele kontrowersji, zwłaszcza w środowiskach konserwatywnych i katolickich. Czołowe argumenty przeciwko tym zapisom, podnoszone w trakcie debaty toczącej się wówczas w mediach, dotyczyły „latarników”, czyli wprowadzenia do szkół osób, które mają pomagać uczniom LGBT doświadczającym przemocy oraz prowadzenia edukacji antydyskryminacyjnej i seksualnej według standardów Światowej Organizacji Zdrowia ${ }^{36}$. Efektem było powołanie przez fundację Mamy i Taty „Ruchu 4 Marca” ${ }^{37}$, którego założyciele domagali się „ochrony dzieci i młodzieży w wieku szkolnym przed deprawacją ideami LGBT"38, a od władz Warszawy wycofania się z deklaracji LGBT+.

Kolejnymi krokami będącymi odpowiedzią na decyzje władz warszawskich, ale również sprzeciwem wobec zamiarów podpisania podobnych deklaracji przez inne miasta, między innymi Poznań i Szczecin, oraz przyjętego w 2018 roku w Gdańsku „Modelu na rzecz równego traktowania” ${ }^{39}$, były podejmowane przez sejmiki województw, powiaty, miasta i gminy „uchwały anty-LGBT”. Do początku sierpnia 2019 roku podjęto ponad trzydzieści uchwał o powstrzymywaniu ideologii LGBT ${ }^{40}$. Zazwyczaj z inicjatywą występowali radni, jako argumentację za poparciem wniosku podając „sprzeciw wobec pojawiających się w sferze publicznej działań zorientowanych na promowanie ideologii ruchów LGBT" 41 . Podnoszono również kwestię wprowadzania elementów wychowania seksualnego w myśl standardów Światowej Organizacji Zdrowia.

W przestrzeni publicznej trwała dalsza eskalacja sporu. W lutym 2020 roku zanotowano dziewięćdziesiąt „,stref wolnych od LGBT”42 wśród jednostek samorządu terytorialnego. W odpowiedzi aktywiści związani ze środowiskiem LGBT utworzyli wirtualny „Atlas nienawiści”43, czyli mapę Polski z zaznaczonymi ośrodkami samorządowymi, w których podjęto „,uchwały anty-LGBT”. Działanie to zostało skrytyko-

${ }^{36}$ Mobilizacja przeciwko warszawskiej deklaracji LGBT. Organizacje rodzinne zawiąują ruch, https://dorzeczy.pl/kraj/95536/Mobilizacja-przeciwko-warszawskiej-deklaracji-LGBT-Organizacje-rodzinne-zawiazuja-ruch.html (dostęp: 11.03.2020).

37 Nazwa pochodzi od dnia powołania ruchu, to jest 4 marca 2019 roku.

38 Stowarzyszenie Ruch 4 Marca: ideologiczna odpowiedź na Kartę LGBT+?, https://www.portalsamorzadowy.pl/polityka-i-spoleczenstwo/stowarzyszenie-ruch-4-marca-ideologiczna-odpowiedz-na-karte-lgbt,122146.html (dostęp: 11.03.2020).

39 Orientacja seksualna, [w:] Model na rzecz równego traktowania, s. 34, https://bip.gdansk.pl/ subpages/akty_prawne/pliki/2018/PMG_2018_7_807_zal01.pdf (dostęp: 2.03.2020).

${ }^{40} \mathrm{~K}$. Kubicka-Żach, Uchwały anty-LGBT przyjmowane raczej „na wyrost”, https://www.prawo.pl/samorzad/uchwaly-anty-lgbt-powody-ich-przyjmowania-przez-rady,456469.html (dostęp: 12.03.2020).

41 Ibidem.

42 D. Uhlig, B. Chyż, Samorzady „wolne od LGBT”. Już prawie 100 miejsc w Polsce, https://wyborcza.pl/7,159116,25733153,samorzady-wolne-od-lgbt-juz-prawie-100-miejsc-w-polsce-mapy. html (dostęp: 27.02.2020).

43 https://atlasnienawisci.pl/ (dostęp: 9.03.2020). 
wane przez środowiska o konserwatywnym światopoglądzie, $w$ tym przez stowarzyszenie „Ordo Iuris”, które przygotowało Samorządową kartę praw rodzin, podpisaną dotąd $^{44}$ przez trzydzieści siedem jednostek samorządowych ${ }^{45}$.

W dniach 24-30 lipca 2019 roku tygodnik „Gazeta Polska” dołączył do wydania naklejkę „Strefa wolna od LGBT”. Paweł Rabiej, wiceprezydent Warszawy, zawiadomił prokuraturę o możliwości popełnienia przestępstwa, zarzucając "Gazecie Polskiej” propagowanie faszyzmu ${ }^{46}$. Prokuratura odmówiła wszczęcia postępowania z powodu braku znamion czynu zabronionego ${ }^{47}$. W innym postępowaniu jednak, toczącym się z powództwa działacza LGBT i organizatora Marszu Równości w Lublinie, sąd nakazał wycofanie naklejek z dystrybucji do czasu rozstrzygnięcia procesu $^{48}$. Niezależnie od trwających czy zapowiadanych procesów sądowych sieć Empik oraz stacje paliw BP, Circle K i Shell odmówiły dystrybucji tego wydania „Gazety Polskiej”, argumentując swoją decyzję między innymi znacznym ryzykiem, że treść naklejki może być sprzeczna z prawem ${ }^{49}$.

Określenie „strefa wolna od LGBT” wykorzystane zostało przez działaczy LGBT w prowokacyjnej akcji, w czasie której aktywiści przymocowali do tablic $\mathrm{z}$ nazwami miejscowości ${ }^{50}$ tabliczki $\mathrm{z}$ takim napisem. Imitowały one prawdziwe znaki informacyjne ${ }^{51}$. Zdjęcia fałszywych tabliczek błyskawicznie rozprzestrzeniły się w mediach społecznościowych, stając się przyczyną ożywionej dyskusji w przestrzeni publicznej i politycznej ${ }^{52}$.

Polskie Towarzystwo Prawa Antydyskryminacyjnego w wydanej opinii prawnej jednoznacznie negatywnie oceniło przyjmowanie przez niektóre sejmiki województw oraz rady gmin i powiatów uchwał przeciwko osobom LGBT+ ${ }^{53}$. Uznało je za działania sprzeczne z prawem, jednocześnie przyznając, że:

44 Stan na dzień 31 marca 2020 roku.

45 https://www.kartarodzin.pl/ (dostęp: 30.03.2020).

46 Prokuratura nie zajmie się nalepka „Strefa wolna od LGBT” w „Gazecie Polskiej”. „Brak znamion czynu zabronionego", https://www.wirtualnemedia.pl/artykul/gazeta-polska-nalepka-strefa-wolna-od-lgbt-prokuratura-nie-wszczyna-postepowania (dostęp: 2.03.2020).

47 Ibidem.

48 Ibidem.

49 Ibidem.

50 Które przyjęły uchwały „anty-LGBT” [podkr. - T.K.].

51 S. Białach, Ordo Iuris szykuje pozwy za akcję aktywistów „Strefy wolne od LGBT”, https://ublin.onet.pl/strefy-wolne-od-lgbt-ordo-iuris-szykuje-pozwy/7rw00p0?utm_source=kobieta.onet. pl_viasg_lublin\&utm_medium=referal\&utm_campaign=leo_automatic\&srcc=ucs\&utm_v=2 (dostęp: 22.03.2020).

52 „Strefy wolne od LGBT” czy raczej bezczelna manipulacja Akcji Demokracja? „Pomawiaja polskie samorzady", https://tysol.pl/a43071--Strefy-wolne-od-LGBT-czy-raczej-bezczelna-manipulacja-Akcji-Demokracja-Pomawiaja-polskie-samorzady- (dostęp: 22.03.2020).

53 M. Szolc, Ocena legalności podejmowanych przez część jednostek samorządu terytorialnego uchwat przeciwko osobom LGBT+, http://ptpa.org.pl/site/assets/files/1845/samorza_dy_ekspertyza_19_07_2019.pdf (dostęp: 9.03.2020). 


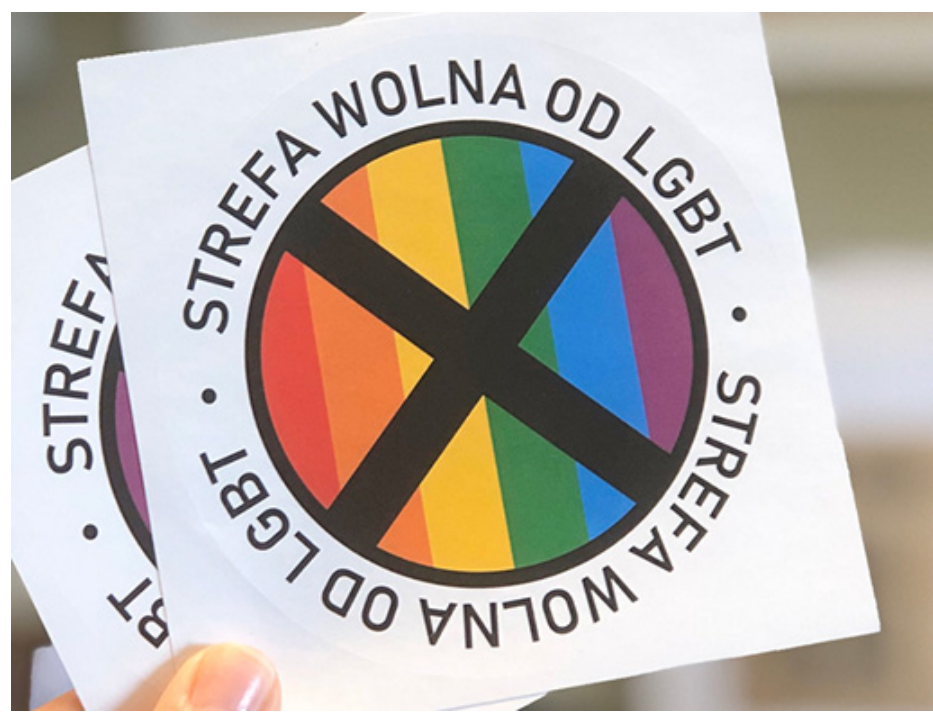

Rys. 1. Naklejka „Strefa wolna od LGBT” dołączona do „Gazety Polskiej” dnia 24 lipca 2019 Źródło: wirtualnemedia.pl.

bezpośrednim powodem, dla którego część jednostek samorządu terytorialnego zaczęła przyjmować uchwały wymierzone w osoby LGBT+, były działania podjęte przez inne samorządy w zakresie działań równościowych i antydyskryminacyjnych. W szczególności ich reakcję wywołała podpisana przez prezydenta m.st. Warszawy i szeroko omawiana w mediach krajowych deklaracja na rzecz społeczności LGBT+ mająca być punktem wyjścia dla stworzenia w przyszłości miejskiej polityk w tym zakresie ${ }^{54}$.

W sprawie omawianych w niniejszym artykule ,uchwał anty-LGBT” Adam Bodnar, Rzecznik Praw Obywatelskich, wyraził pogląd, że są one sprzeczne z prawem europejskim $^{55}$. W jego opinii naruszają one „prawo do poszanowania życia prywatnego i rodzinnego, wolności wypowiedzi oraz zakazu dyskryminacji ze względu na orientację seksualną i tożsamość płciową" ${ }^{56}$. Między innymi z tego powodu pod koniec 2019 roku skierował do sądów skargi na wybrane uchwały rad gmin ${ }^{57}$, a na początku marca 2020 roku zarzuty te rozszerzył, dodając nowe skargi ${ }^{58}$.

18 grudnia 2019 roku Parlament Europejski przyjął rezolucję w sprawie „uchwał anty-LGBT", wzywającą Polskę do wycofania się z przedmiotowych postanowień.

${ }^{54}$ Ibidem.

${ }^{55}$ Uchwaty „anty-LGBT” - sprzeczne także z prawem europejskim. Nowe zarzuty skarg RPO do sądów $i$ kolejne skargi, https://www.rpo.gov.pl/pl/content/rpo-uchwaly-anty-lgbt-sprzeczne-takze-z-prawem-europejskim (dostęp: 17.03.2020).

56 Ibidem.

57 Ibidem. Skargi dotyczyły gmin: Istebna (województwo śląskie), Lipinki (województwo małopolskie), Klwów (województwo mazowieckie), Serniki (województwo lubelskie), Niebylec (województwo podkarpackie).

58 Ibidem. 
Jednocześnie Parlament zaapelował do Komisji Europejskiej o zweryfikowanie, w jaki sposób samorządy, w których przyjęto uchwały, wydają środki z unijnego budżetu. Na początku 2020 roku treść rezolucji została dostarczona przedstawicielom wszystkich 2807 województw, powiatów i gmin z całej Polski ${ }^{59}$.

Partia Zieloni w reakcji na działania stosowane coraz częściej przez polskie samorządy postanowiła z kolei poinformować ich partnerskie miasta w Europie Zachodniej o treści podejmowanych uchwał ${ }^{60}$. Zielonych w tym postępowaniu wsparła redakcja portalu OKO.press, wysyłając „obywatelskie donosy” do pięćdziesięciu dwóch unijnych partnerów trzynastu polskich gmin i rejonów, które przyjęly uchwały „anty-LGBT", do zerwania umów o współpracy ${ }^{61}$. W efekcie działań wymienionych w poprzedniej części niniejszego opracowania nastąpiła reakcja ze strony niektórych miast partnerskich z Europy Zachodniej. Pierwszym sygnałem, świadczącym o wyraźnym rozdźwięku pomiędzy dotychczasowymi samorządowymi sojusznikami, było zerwanie partnerstwa pomiędzy Saint-Jean-de-Braye a Tuchowem. Przypadek ten został poddany szerszej analizie w kolejnym rozdziale niniejszego opracowania.

Spośród ujawnionych przypadków rezygnacji, zawieszenia lub zapowiedzi zawieszenia współpracy uwagę zwraca także decyzja francuskiego Regionu Centralnego Doliny Loary, który zawiesił współpracę z Małopolską. Była to reakcja na przyjęcie w dniu 29 kwietnia 2019 roku przez sejmik województwa małopolskiego deklaracji „W sprawie sprzeciwu wobec wprowadzenia ideologii LGBT do wspólnot samorządowych"62. W komunikacie władz francuskiego regionu z dnia 24 lutego 2020 roku podano, że „zawieszenie potrwa do momentu, aż w Małopolsce zostanie przywrócone pełne poszanowanie praw człowieka, zgodnie z wartościami Unii Europejskiej" ${ }^{63}$. Współpraca obejmowała wymianę w szkołach średnich, wspólne wydarzenia kulturalne oraz naukowe. Strona RMF24.pl, podając za portalem Onet.pl, przypomniała, że jest to kolejny francuski region, który zdecydował się na takie posunięcie względem niedawnego jeszcze partnera ${ }^{64}$. Przypomina

59 T. Klyta, Wszystkie polskie samorządy dostały pisma od Kampanii Przeciw Homofobii, https:// www.portalsamorzadowy.pl/polityka-i-spoleczenstwo/wszystkie-polskie-samorzady-dostaly-pisma-od-kampanii-przeciw-homofobii,146903.html (dostęp: 19.03.2020).

60 Zieloni pisza do miast partnerskich $z$ catej Europy w sprawie uchwat anty-LGBT, https://partiazieloni.pl/zieloni-pisza-do-miast-partnerskich-z-calej-europy-w-sprawie-uchwal-anty-lgbt/ (dostęp: 16.03.2020).

61 A. Ambroziak, P. Pacewicz, Wysyłamy 52 donosy na „strefy wolne od LGBT” do bliźniaczych regionów UE. Zerwijcie umowę!, https://oko.press/wysylamy-52-donosy-na-strefy-wolne-od-lgbt-do-blizniaczych-regionow-ue-zerwijcie-umowe/ (dostęp: 6.03.2020).

${ }^{62}$ Deklaracja $\mathrm{nr}$ 1/19 Sejmiku Województwa Małopolskiego $z$ dnia 29 kwietnia 2019 roku w sprawie sprzeciwu wobec wprowadzenia ideologii „LGBT” do wspólnot samorządowych, https://bip.malopolska.pl/umwm,a,1594074,deklaracja-nr-119-sejmiku-wojewodztwa-malopolskiego-z-dnia-29-kwietnia-2019-r-w-sprawie-sprzeciwu-wo.html (dostęp: 13.03.2020).

${ }^{63}$ S. Czapliński, Nie tylko Tuchów podjął uchwałe „anty-LGBT”, https://www.temi.pl/region/powiat-tarnowski/nie-tylko-tuchow-podjal-uchwale-anty-lgbt/ (dostęp: 23.03.2020).

${ }^{64}$ N. Makarewicz, „Strefy wolne od LGBT”. Francuski region zawiesza wspótpracę z Małopolska, https://www.rmf24.pl/fakty/polska/news-strefy-wolne-od-lgbt-francuski-region-zawiesza-wspol- 
również o wcześniejszym przypadku Tuchowa i Saint-Jean-de-Braye oraz decyzji o zerwaniu partnerstwa pomiędzy Noget-Sur-Oise a Kraśnikiem, które, decyzją władz podparyskiej miejscowości, nastąpiło 20 lutego 2020 roku $^{65}$.

Z licznych przekazów medialnych związanych z kwestiami zawieszania bądź zrywania współpracy, które docierają do publiczności, przebija się jeszcze kilka wątków wartych zasygnalizowania. Według zapowiedzi do przedstawionych przykładów w niedługim czasie mogą dołączyć kolejne regiony i miasta. Są to między innymi gmina Stary Sącz, z którą umowę partnerską chce zerwać kolejne francuskie miasto, Lambres-Lez-Douai ${ }^{66}$, Puławy, gdzie współpracę zawiesiło już Douai (również Francja), a podobne kroki zamierza podjąć niemieckie Stendal ${ }^{67}$, oraz Nowa Dęba, z którą oficjalne formy współpracy zamierza wypowiedzieć irlandzkie miasto Fermoy ${ }^{68}$.

\section{Analiza możliwych skutków prawnych, społecznych i kulturowych zerwania partnerstwa na przykładzie Saint-Jean-de-Braye i Tuchowa}

W rozdziale tym zostanie podjęta próba analizy faktycznych skutków zakończenia współpracy pomiędzy wspomnianymi w tytule miastami.

Tuchów to osiemnastotysięczna gmina położona w województwie małopolskim ${ }^{69}$, licząca zaś ponad dwadzieścia tysięcy mieszkańców Saint-Jean-de-Braye leży we francuskim departamencie Loiret. Obie gminy podpisały umowę o partnerstwie w 1994 roku. Francuscy radni 14 lutego 2020 roku podjęli decyzję o zakończeniu trwającej dwadzieścia pięć lat współpracy, czym, według władz Tuchowa, zaskoczyli stronę polską ${ }^{70}$. Francuskie media, które informowały o tej decyzji, podkreślały, że zapadła jednogłośnie i była wyrazem sprzeciwu wobec przejawów

prace-z-,nId,4346755 (dostęp: 23.03.2020).

65 Ibidem.

66 J. Bobrek, Stary Sącz straci francuskiego partnera przez rezolucję przeciwko LGBT i ideologii gender?, https://gazetakrakowska.pl/stary-sacz-straci-francuskiego-partnera-przez-rezolucje-przeciwko-lgbt-i-ideologii-gender/ar/c1-14814644 (dostęp: 23.03.2020).

67 M. Pankowska, Francuskie Douai zawiesza wspólpracę $z$ Puławami za strefę anty LGBT. Mer: „Przemoc zaczyna się od słów”, https://oko.press/francuskie-douai-zawiesza-wspolprace-z-pulawami-za-strefe-anty-lgbt-mer-przemoc-zaczyna-sie-od-slow/ (dostęp: 23.03.2020).

68 A. Janik, Nowa Dęba straci miasto partnerskie w Irlandii, bo jest anty-LGBT?, https://nowiny24.pl/nowa-deba-straci-miasto-partnerskie-w-irlandii-bo-jest-antylgbt/ar/c1-14841176 (dostęp: 23.03.2020).

${ }^{69} \mathrm{https} / / /$ www.tuchow.pl/ (dostęp: 24.03.2020).

70 S. Czapliński, Nie chca partnerstwa $z$ powodu uchwaly „anty-LGBT+”, https://www.temi.pl/ region/powiat-tarnowski/nie-chca-partnerstwa-z-powodu-uchwaly-anty-lgbt/ (dostęp: 12.03.2020). 
łamania praw człowieka ${ }^{71}$. Według Agaty Szczerbiak przykład Saint-Jean-de-Braye o wycofaniu się ze współpracy z Tuchowem to początek dyskusji o możliwych zagranicznych reperkusjach wobec polskich samorządów, które przyjęły podobne w swoim wydźwięku uchwały ${ }^{72}$. W obszernym artykule opublikowanym w tygodniku „Polityka” autorka podaje również, że pod hasłami chcącymi zatrzymania przez władze samorządowe „ideologii LGBT” lub „ideologii gender” kryją się w istocie sankcje „wymierzone w osoby deklarujące się jako geje, lesbijki, osoby transseksualne i biseksualne oraz inne nieheteronormatywne"73. W opiniach francuskich mediów, powołujących się na słowa Colette Martin-Chabbert, odpowiedzialnej w gminie za relacje zagraniczne, wskazywano, że w Polsce „rządząca partia przekazuje homofobię”, a wykluczanie osób homoseksualnych to sygnał, że „historia niestety się powtarza". Podkreślano, że strona francuska nie może zaakceptować tego typu decyzji, podejmowanych „wbrew prawom człowieka”.

Zdaniem Magdaleny Marszałek, burmistrza Tuchowa, sprawa powinna zostać wyjaśniona pomiędzy partnerskimi samorządami choćby ze względu na wspólną, dwudziestopięcioletnią historię; tymczasem tuchowianie zostali postawieni przed faktem dokonanym ${ }^{74}$. Choć samą uchwałę podjętą przez tuchowski samorząd uważa za niewłaściwą, to dostrzega, że decyzja strony francuskiej, ze względu na zbliżające się tam wybory samorządowe miała podtekst polityczny i była sposobem na pozyskanie przychylności określonych grup wyborców ${ }^{75}$. Burmistrz Tuchowa zapowiedziała także ponowne rozpatrzenie "uchwały anty-LGBT” podczas najbliższej sesji rady gminy. Równocześnie twierdzi, że dalsza współpraca z francuską gminą nie jest możliwa, gdyż „swoją decyzją francuscy radni obrazili naszą lokalną społeczność" 76 .

Akt podpisania umowy o partnerstwie pomiędzy miastami czy regionami zazwyczaj jest doniosłym wydarzeniem poprzedzonym wieloetapowymi działaniami. Jak dotąd nie odnotowano natomiast przypadków zerwania czy też zakończenia współpracy z powodów podobnych do omawianych w niniejszym artykule (nie jest poruszana kwestia powolnego zamierania partnerstwa, na przykład z powodu ustania bądź bardzo rzadkich kontaktów). Przechodząc do analizy faktycznych następstw, zerwania partnerstwa pomiędzy przedstawionymi gminami, postanowiono podzielić je na skutki prawne, społeczne i kulturowe, zachowując separację na

71 Radny PiS: Będziemy się sprzeciwiać agresywnej homopropagandzie, https://wiadomosci. dziennik.pl/wydarzenia/artykuly/6442581,strefa-wolna-od-lgbt-tuchow-francja-kontakty.html (dostęp: 11.03.2020).

72 A. Szczerbiak, Strefy bez LGBT czy bez nienawiści? Samorządowa kontrrewolucja, https:// www.polityka.pl/tygodnikpolityka/spoleczenstwo/1943042,1,strefy-bez-lgbt-czy-bez-nienawisci-samorzadowa-kontrrewolucja.read (dostęp: 12.03.2020).

73 Ibidem.

74 S. Czapliński, Nie chca partnerstwa z powodu uchwały...

75 Ibidem.

76 Ibidem. 
te, które mogą odnosić się do funkcjonowania gminy jako jednostki samorządowej, oraz te, które mogą dotyczyć zamieszkującej ten obszar społeczności.

Skutki prawne:

- dla gminy: zgodnie z art. 2.1 ustawy z dnia 15 września 2000 roku o zasadach przystępowania jednostek samorządu terytorialnego do międzynarodowych zrzeszeń społeczności lokalnych i regionalnych ,jednostki samorządu terytorialnego mogą przystępować do zrzeszeń i uczestniczyć w nich w granicach swoich zadań i kompetencji, działając zgodnie z polskim prawem wewnętrznym, polityką zagraniczną państwa i jego międzynarodowymi zobowiązaniami" ${ }^{\prime 7}$. Oznacza to, że w myśl kolejnych artykułów wzmiankowanej ustawy, gmina, przystępując do omawianego partnerstwa, zobowiązana była podjąć stosowną uchwałę, a następnie przekazać ją ministrowi właściwemu do spraw zagranicznych za pośrednictwem wojewody. Artykuł 7 ustawy nakłada podobny obowiązek informacyjny względem władz centralnych „w przypadku wystąpienia jednostki samorządu terytorialnego ze zrzeszenia, a także w przypadku rozwiązania zrzeszenia"78;

- dla mieszkańców: brak skutków prawnych; partnerstwo pomiędzy miastami czy regionami lub zakończenie partnerstwa nie ma skutków prawnych dla obywateli.

Skutki społeczne:

- dla gminy: współpraca między lokalnymi władzami pozwala na poznanie i wdrożenie różnorakich świadczeń, usług, kształcenia, budownictwa czy pomocy socjalnej. Jak pisze Joanna Szewczyk: „wizyty przedstawicieli władz oraz pracowników urzędów gminnych pozwalają na poznanie różnych metod pracy, wymianę doświadczeń w sprawowaniu władzy i prowadzeniu polityki lokalnej. Spotkania te służą także eliminowaniu błędów pojawiających się w przeszłości oraz unikaniu tych samych błędów w przyszłości”79. Można zatem uznać, że modelowo prowadzona współpraca partnerska powinna przynosić wymierne i wzajemne korzyści we wskazanym zakresie. W toku zbierania materiałów do niniejszego artykułu nie natrafiono jednak na przykłady dotyczące omawianych gmin, które mogłyby jednoznacznie potwierdzić istnienie bilateralnych programów, które w czasie trwania partnerstwa Saint-Jean-de-Braye i Tuchowa miały wymierne skutki społeczne dla gminy;

- dla mieszkańców: lektura kroniki wydarzeń związanych z miastami partnerskimi Tuchowa ${ }^{80}$ skłania do stwierdzenia, że w ciągu dwudziestu pięciu lat istnienia współpracy podejmowano wiele dwustronnych kontaktów, w których uczestniczyła lokalna społeczność. Najczęściej wskazywano wymiany młodzieży, mieszkańców, grup i zespołów artystycznych czy sportowych. Współpraca realizo-

77 http://isap.sejm.gov.pl/isap.nsf/download.xsp/WDU20000911009/U/D20001009Lj.pdf (dostęp: 22.03.2020).

78 Ibidem.

79 J. Szewczyk, op. cit., s. 270.

${ }^{80}$ Miasta bliźniacze, https://www.tuchow.pl/gmina-tuchow/miasta-blizniacze/ (dostęp: 20.03.2020). 
wana była również poprzez wizyty władz samorządowych, seminaria, konferencje, wizyty grupowe mieszkańców, imprezy kulturalne, sportowe i promocyjne ${ }^{81}$. Zerwanie partnerstwa mogło więc mieć negatywne skutki dla działań rozpoczętych wcześniej przez lokalne społeczności.

Skutki kulturowe:

- dla gminy: wymiany w zakresie edukacji i kształcenia były jednymi z podstawowych form działania w ramach partnerstwa; zakończenie tej formy aktywności oznaczać może, $\mathrm{z}$ jednej strony, brak konieczności zapewnienia w budżecie gminy odpowiednich środków na ten cel, z drugiej zaś — ograniczenie możliwości edukacji mieszkańców korzystających z kształcenia za granicą;

- dla mieszkańców: wymiana z zaprzyjaźnioną gminą pozwala im poznać różnice między funkcjonowaniem $w$ dwóch różnych krajach. Jest również okazją do nawiązania kontaktów oraz nauki języków obcych. Obecność na sympozjach, targach, konferencjach, festiwalach, turniejach sportowych czy koncertach poszerza zrozumienie dla środowiska kulturowego bliźniaczej gminy. Nasuwa się wniosek, że zerwanie partnerstwa dla mieszkańców mogło być skutkiem negatywnym. Nie należy jednak zapominać, że nastąpiło to na skutek działania strony francuskiej jako reakcja na „uchwałę anty-LGBT”, podjętą przez radnych reprezentujących mieszkańców gminy Tuchów. Kulturowe skutki zerwania partnerstwa mogą być zatem oceniane zarówno jako negatywne, jak i pozytywne, w zależności od miary, jaką będziemy przykładać do problemu.

Widzimy więc, że zarówno skutków prawnych, społecznych, jak i kulturowych nie można określić jednoznacznie. Istotne skutki, z punktu widzenia jednostki samorządu terytorialnego, mogą nie odgrywać większego znaczenia, być równie ważne lub zdecydowanie ważniejsze w przypadku samych mieszkańców, którzy mogli korzystać z partnerskich programów.

\section{Podsumowanie}

Z zestawienia przygotowanego przez aktywistów LGBT wynika, że do końca lutego 2020 roku „uchwałę anty-LGBT” przyjęły dziewięćdziesiąt trzy jednostki samorządu terytorialnego w Polsce. Wśród nich były to pięćdziesiąt dwie uchwały przeciwko „ideologii LGBT”, trzydzieści siedem Samorządowych Kart Praw Rodzin (SKPR) oraz dziewięć własnych uchwał - łącznie dziewięćdziesiąt osiem tego typu deklaracji ${ }^{82}$.

Tuchów, który jako pierwszy utracił status miasta partnerskiego z odpowiednikiem z terenu Unii Europejskiej, ma podpisane umowy partnerskie jeszcze z siedmioma innymi europejskimi miejscowościami. Są to: Baranówka (Ukraina), Detva

${ }^{81}$ Ibidem.

82 T. Żółciak, Lewica tropi uchwały anty-LGBT samorządów, https://www.gazetaprawna.pl/artykuly/1457187, anty-lgbt-uchwala-rady-gminy.html (dostęp: 23.03.2020). 
(Słowacja), Illingen (Niemcy), Martfü (Węgry), Mikulov (Czechy), Pettenbach (Austria) i Tăuţii-Măgherăuş (Rumunia) ${ }^{83}$. Mimo zerwania partnerstwa przez francuskie Saint-Jean-de-Braye nie ma jak dotąd sygnałów świadczących o chęci podjęcia podobnych kroków przez inne współpracujące miasta. Należy się jednak liczyć z możliwościami, że podobne w swych konsekwencjach decyzje podejmą kolejne zagraniczne miasta i regiony partnerskie wobec innych polskich samorządów.

To przypuszczenie ma swoje podłoże w obserwacji zmian kulturowych, zachodzących w Europie i Polsce od końca XX wieku. Ma to bezpośredni związek z niniejszym opracowaniem, choć należy dodać, że wspomniane zmiany dotyczą także przeważającego obszaru naszego globu.

Grzegorz Żuk, analizując wypowiedzi filozofów reprezentujących odmienne stanowiska $w$ kwestii zachodzących na świecie zmian kulturowych, uważa, że mamy do czynienia z kryzysem cywilizacji, którego przyczyną jest zerwanie $\mathrm{z}$ tradycją ${ }^{84}$. Bazując na potrzebach wyższych człowieka, przedstawia kanon tradycyjnych wartości kulturowych, który dzieli na cztery sfery wartości: osobiste (życie, wolność i godność), wspólnotowe (rodzina, wspólnota i religia), absolutne (prawda, dobro, piękno oraz Bóg) oraz wartości wspólnotowe obecnie dominujące w kulturze Zachodu (pluralizm, demokracja i tolerancja) ${ }^{85}$. Autor zaznacza, że kanon nie ma charakteru obowiązkowego, nie zapobiega też istnieniu odmiennych stanowisk, poglądów czy antagonizmów, co może prowadzić do konfliktów (między innymi takich jak przedstawione w niniejszym opracowaniu $)^{86}$. Jak zauważa:

Na poziomie wspólnoty konflikty wartości mają zazwyczaj źródło w rozbieżności między kanonem wartości tradycyjnych a zestawem wartości propagowanych przez zwolenników idei postępu. Innymi słowy: między ideologią konserwatywną, odwołującą się do wartości tradycyjnych, a ideologią liberalną, która rezygnuje z wartości absolutnych, do sfery wartości wspólnotowych wpisuje zaś pluralizm, demokrację i tolerancję ${ }^{87}$.

Podsumowując rozważania na temat konfliktów wartości i konfliktów wspólnotowych, Żuk, odnosząc się do cytowanych autorytetów (Gadamer, Tischner, Pomian, Bellah), określa zaistniałą sytuację mianem kryzysu cywilizacji, który szczególnie dotknął państwa zachodnie ${ }^{88}$. Tym samym właściwe wydaje się umiejscowienie omawianych $\mathrm{w}$ niniejszym artykule kwestii właśnie w ujęciu kulturowym, a nie jedynie prawnym czy społecznym.

Ze względu na aktualność problemu oraz jego rozwojowy charakter trudno z całą stanowczością stwierdzić, czy będzie on dalej eskalować. Zbyt wcześnie jesz-

${ }^{83}$ A. Teliszewski, SKANDAL! Francuzi zrywają wspótpracę z Tuchowem! Wszystko przez uchwałe anty-LGB, https://www.se.pl/tarnow/skandal-francuzi-zrywaja-wspolprace-z-tuchowem-wszystko-przez-uchwale-anty-lgbt-aa-ESi6-F8Rv-wbvu.html (dostęp: 9.03.2020).

${ }^{84}$ G. Żuk, Edukacja aksjologiczna. Zarys problematyki, Lublin 2016, s. 116.

85 Ibidem.

86 Ibidem.

87 Ibidem.

${ }^{88}$ Ibidem. 
cze, by określać, czy stanie się to problemem powszechnym wśród sygnatariuszy stowarzyszonych miast i regionów, czy też może prezentowane w niniejszym opracowaniu przykłady będą jedynie wyjątkami we współpracy partnerskiej. Z pewnością można jednak zaryzykować twierdzenie, że na tle historycznym międzynarodowej współpracy ośrodków regionalnych wydarzenia prezentowane w artykule są wyjątkowe. Z jednej strony dotyczą jednostkowych przykładów (obecnie) tego, że odmienne stanowiska radnych doprowadziły do zerwania partnerstwa (vide: Tuchów), z drugiej — możliwość nasilania się problemu, w związku z jego potencjałem (liczba podpisanych umów o partnerstwie oraz tendencje do podejmowania „uchwał anty-LGBT” przez kolejne samorządy), nakazuje dalszą obserwację przedstawionego zagadnienia.

W ocenie autora jednak omawiane kwestie mają jeszcze jeden wymiar. Nawiązując do cytowanych we wstępie słów profesora Jerzego Marchwińskiego, udało się ukazać pewne niedoskonałości w funkcjonowaniu umów o partnerstwie miast, gmin i regionów. W chwili wystąpienia problemu zabrakło prób odniesienia się do wartości, które powinny być podstawą dobrze rozumianego partnerstwa. Strony sporu zamknęły się w szczególności na takt w rozwiązywaniu napięć, gotowość rozumienia odmienności partnera, odpowiedzialność, otwarcie na dialog i zdolność do akceptowania kompromisu.

\section{Bibliografia}

Ambroziak A., Pacewicz P., Wysyłamy 52 donosy na „strefy wolne od LGBT” do bliźniaczych regionów UE. Zerwijcie umowę!, https://oko.press/wysylamy-52-donosy-na-strefy-wolne-od-lgbt-do-blizniaczych-regionow-ue-zerwijcie-umowe/.

Bär A., Sieć zaufania, https://www.goethe.de/ins/pl/pl/kul/mag/21444138.html.

Białach S., Ordo Iuris szykuje pozwy za akcje aktywistów „Strefy wolne od LGBT”, https://lublin. onet.pl/strefy-wolne-od-lgbt-ordo-iuris-szykuje-pozwy/7rw00p0?utm_source=kobieta.onet. pl_viasg_lublin\&utm_medium =referal\&utm_campaign=leo_automatic\&srcc=ucs\&utm_v=2.

Bobrek J., Stary Sacz straci francuskiego partnera przez rezolucje przeciwko LGBT i ideologii gender?, https://gazetakrakowska.pl/stary-sacz-straci-francuskiego-partnera-przez-rezolucje-przeciwko-lgbt-i-ideologii-gender/ar/c1-14814644.

Czapliński S., Nie chca partnerstwa z powodu uchwaly „anty-LGBT+”, https://www.temi.pl/region/ powiat-tarnowski/nie-chca-partnerstwa-z-powodu-uchwaly-anty-lgbt/.

Czapliński S., Nie tylko Tuchów podjął uchwałe „,anty-LGBT”, https://www.temi.pl/region/powiat-tarnowski/nie-tylko-tuchow-podjal-uchwale-anty-lgbt/.

Deklaracja nr 1/19 Sejmiku Województwa Małopolskiego z dnia 29 kwietnia 2019 roku w sprawie sprzeciwu wobec wprowadzenia ideologii „LGBT” do wspólnot samorzadowych, https://bip.malopolska.pl/umwm,a,1594074,deklaracja-nr-119-sejmiku-wojewodztwa-malopolskiego-z-dnia-29-kwietnia-2019-r-w-sprawie-sprzeciwu-wo.html.

Dziesięć kroków do sukcesu, http://www.twinning.org/pl/page/dziesi\%C4\%99\%C4\%87-krok\%C3\%B3w-do-sukcesu\#.XpT5D2DgrIU.

Gackowski T., Metodologie badań medioznawczych, Warszawa 2014.

Gackowski T., Brylska K., Patera M., Korzystanie z mediów społecznościowych jako praktyka społeczna różnych pokoleń medialnych, Warszawa 2018. 
https://atlasnienawisci.pl/.

https://www.kartarodzin.pl/.

Izdebski H., Samorzad terytorialny. Podstawy ustroju i działalności, Warszawa 2011.

Janik A., Nowa Dęba straci miasto partnerskie w Irlandii, bo jest anty-LGBT?, https://nowiny24.pl/ nowa-deba-straci-miasto-partnerskie-w-irlandii-bo-jest-antylgbt/ar/c1-14841176.

Jerzy Marchwiński, https://culture.pl/pl/tworca/jerzy-marchwinski.

Klyta T., Wszystkie polskie samorzady dostały pisma od Kampanii Przeciw Homofobii, https://www. portalsamorzadowy.pl/polityka-i-spoleczenstwo/wszystkie-polskie-samorzady-dostaly-pisma-od-kampanii-przeciw-homofobii,146903.html.

Kubica B., Jak górnicy z Rybnika swoja przyjaźń z miastem zza „żelaznej kurtyny” zaczynali, https:// plus.dziennikzachodni.pl/jak-gornicy-z-rybnika-swoja-przyjazn-z-miastem-zza-zelaznej-kurtyny-zaczynali/ar/4995386.

Kubicka-Żach K., Uchwały anty-LGBT przyjmowane raczej „na wyrost”, https://www.prawo.pl/samorzad/uchwaly-anty-lgbt-powody-ich-przyjmowania-przez-rady,456469.html.

Lisowska-Magdziarz M., Analiza zawartości mediów. Przewodnik dla studentów. Wersja 1.1, Kraków 2004.

Makarewicz N., „Strefy wolne od LGBT”. Francuski region zawiesza wspótpracę z Małopolską, https:// www.rmf24.pl/fakty/polska/news-strefy-wolne-od-lgbt-francuski-region-zawiesza-wspolprace-z-,nId,4346755.

Marchwiński J., Definicja partnerstwa. Próba wyjaśnienia pojęcia, http://jerzy-marchwinski.blogspot. com/2014/04/definicja-partnerstwa.html.

Miasta bliźniacze, https://www.tuchow.pl/gmina-tuchow/miasta-blizniacze/.

Miasta partnerskie - dlaczego warto współpracować, https://samorzad.infor.pl/sektor/rozwoj_i_promocja/wspolpraca/2960129,Miasta-partnerskie-dlaczego-warto-wspolpracowac.html.amp.

Michalak J., Prezydent stolicy podpisał Deklaracje LGBT+, https://www.um.warszawa.pl/aktualnosci/ prezydent-stolicy-podpisa-deklaracj-lgbt.

Misztal M., Rola samorządów lokalnych $w$ kształtowaniu tolerancji i integracji międzynarodowej, „Ekonomiczne Problemy Usług” 61, 2010, nr 620.

Mobilizacja przeciwko warszawskiej deklaracji LGBT. Organizacje rodzinne zawiąują ruch, https:// dorzeczy.pl/kraj/95536/Mobilizacja-przeciwko-warszawskiej-deklaracji-LGBT-Organizacje-rodzinne-zawiazuja-ruch.html.

Nitschke-Szram B., Międzynarodowa wspótpraca samorządów, „Opinie i Ekspertyzy”, nr 261, Warszawa 2017.

Orientacja seksualna, [w:] Model na rzecz równego traktowania, s. 34, https://bip.gdansk.pl/subpages/ akty_prawne/pliki/2018/PMG_2018_7_807_zal01.pdf.

Pankowska M., Francuskie Douai zawiesza wspótpracę $z$ Puławami za strefę anty LGBT. Mer: „Przemoc zaczyna się od słów", https://oko.press/francuskie-douai-zawiesza-wspolprace-z-pulawami-za-strefe-anty-lgbt-mer-przemoc-zaczyna-sie-od-slow/.

Pawłuszko T., Wstęp do metodologii badań politologicznych, Częstochowa 2013.

Prokuratura nie zajmie się nalepka „Strefa wolna od LGBT” w „Gazecie Polskiej”. „Brak znamion czynu zabronionego", https://www.wirtualnemedia.pl/artykul/gazeta-polska-nalepka-strefa-wolna-od-lgbt-prokuratura-nie-wszczyna-postepowania.

Rada Gmin i Regionów Europy (CEMR), https://www.zpp.pl/artykul/62-rada-gmin-i-regionow-europy-cemr.

Radny PiS: Będziemy się sprzeciwiać agresywnej homopropagandzie, https://wiadomosci.dziennik.pl/ wydarzenia/artykuly/6442581,strefa-wolna-od-lgbt-tuchow-francja-kontakty.html.

Stowarzyszenie Ruch 4 Marca: ideologiczna odpowiedź na Kartę LGBT+?, https://www.portalsamorzadowy.pl/polityka-i-spoleczenstwo/stowarzyszenie-ruch-4-marca-ideologiczna-odpowiedz-na-karte-lgbt,122146.html. 
„Strefy wolne od LGBT" czy raczej bezczelna manipulacja Akcji Demokracja? Pomawiaja polskie samorzady, https://tysol.pl/a43071--Strefy-wolne-od-LGBT-czy-raczej-bezczelna-manipulacja-Akcji-Demokracja-Pomawiaja-polskie-samorzady-.

Szczerbiak A., Strefy bez LGBT czy bez nienawiści? Samorządowa kontrrewolucja, https://www. polityka.pl/tygodnikpolityka/spoleczenstwo/1943042,1,strefy-bez-lgbt-czy-bez-nienawisci-samorzadowa-kontrrewolucja.read.

Szewczak M., Wieczorek I., Współpraca międzynarodowa miast polskich. Doświadczenia JST, Łódź 2018.

Szewczyk J., Zagraniczne związki partnerskie polskich samorządów miast, powiatów i województw, „Prace Geograficzne”, z. 117, Kraków 2007.

Szolc M., Ocena legalności podejmowanych przez część jednostek samorządu terytorialnego uchwał przeciwko osobom LGBT+, http://ptpa.org.pl/site/assets/files/1845/samorza_dy_ekspertyza_19 _07_2019.pdf.

Szymańska A., Lisowska-Magdziarz M., Hess A., Metody badań medioznawczych i ich zastosowanie, Kraków 2018.

Teliszewski A., Skandal! Francuzi zrywaja współpracę z Tuchowem! Wszystko przez uchwałę anty-LGB, https://www.se.pl/tarnow/skandal-francuzi-zrywaja-wspolprace-z-tuchowem-wszystko-przez-uchwale-anty-lgbt-aa-ESi6-F8Rv-wbvu.html.

Uchwały „anty-LGBT” - sprzeczne także z prawem europejskim. Nowe zarzuty skarg RPO do sądów $i$ kolejne skargi, https://www.rpo.gov.pl/pl/content/rpo-uchwaly-anty-lgbt-sprzeczne-takze-z-prawem-europejskim.

Uhlig D., Chyż B., Samorzady „wolne od LGBT”. Już prawie 100 miejsc w Polsce, https://wyborcza. $\mathrm{pl} / 7,159116,25733153$,samorzady-wolne-od-lgbt-juz-prawie-100-miejsc-w-polsce-mapy.html.

Wieczorek I., Głąb A., Zadania administracji samorządowej w zakresie wspótpracy transgranicznej, [w:] Wybrane aspekty współpracy transgranicznej polskich samorząów w kontekście przemian prawa Unii Europejskiej, red. I.M. Wieczorek, M. Ganczar, Łódź 2016.

Wieliczko M., Od Gauadalajary do Ramat Gan - umowy partnerskie Wrocławia, https://www.wroclaw.pl/portal/miasta-partnerskie-wroclawia.

Wspólpraca miast partnerskich, http://www.miasta.pl/strony/wspolpraca-miast-partnerskich.

Zieloni pisza do miast partnerskich z całej Europy w sprawie uchwał anty-LGBT, https://partiazieloni. $\mathrm{pl} /$ zieloni-pisza-do-miast-partnerskich-z-calej-europy-w-sprawie-uchwal-anty-lgbt/.

Żuk G., Edukacja aksjologiczna. Zarys problematyki, Lublin 2016.

Żółciak T., Lewica tropi uchwały anty-LGBT samorzadów, https://www.gazetaprawna.pl/artykuly/ 1457187,anty-lgbt-uchwala-rady-gminy.html. 